\title{
The effects of dietary energy restriction on overloaded skeletal muscle in rats
}

\author{
Khalid Almurshed $\dagger$ and Katharine Grunewald* \\ Department of Human Nutrition, Kansas State University, Manhattan, KS 66506-1407, USA
}

(Received 24 September 1999 - Revised 6 March 2000 - Accepted 18 April 2000)

\begin{abstract}
We evaluated the effects of three levels of energy intake, $73 \%$ (CON73), $81 \%$ (CON81) and $100 \%$ (CON100) of the ad libitum intake of the control diet, on skeletal muscle growth induced by functional overload in male rats. Unlike most previous studies which have employed chronic or acute food restriction where all nutrients are reduced in the diet, the present study tested the effects of energy deprivation as a single factor without inducing other nutritional deficiencies. Muscular growth of plantaris and soleus muscles was induced by removal of synergist gastrocnemius muscles in one hindlimb; muscles in the other leg were used as sham-operated intra-animal controls. After $30 \mathrm{~d}$, rats on the energy-restricted CON73 and CON81 diets gained less weight and had smaller livers, kidneys, hearts and fat pads (epididymal, retroperitoneal and omental) than CON100 rats $(P<0.05)$. They also had smaller sham-operated plantaris muscles $(\mathrm{CON} 73-13 \%, \mathrm{CON} 81-9 \%)$ containing less total protein $(\mathrm{CON} 73-14 \%$; CON81 $-10 \%)$ than CON100 rats $(P<0 \cdot 05)$. However, the same measurements in overloaded plantaris muscles were similar among groups. Soleus muscle mass and protein contents were not significantly affected by energy restriction in our study. Percentage distributions of myosin heavy-chain isoforms (types I, IIa, IIx and IIb) were similar among rats in CON100, CON81 and CON73 groups for both plantaris and soleus muscles. We conclude that the growth reduction of plantaris muscle induced by energy restriction at $73 \%$ and $81 \%$ for $30 \mathrm{~d}$ was prevented by functional overload in male rats.
\end{abstract}

Dietary energy: Skeletal muscle: Muscular overload

Growth of skeletal muscle is a normal biological process that occurs in man and other animal species (Young, 1970; Goldspink, 1980; Layman et al. 1980). However, muscular growth can be reduced or compromised by a nutritionallyinadequate diet. For example, a reduction in energy intake decreases several indices of muscular growth, including overall size (Hegarty \& Kim, 1981; Bedi et al. 1982; Lewis \& Sieck, 1992), cross-sectional area (Glore \& Layman, 1983; Lanz et al. 1992; Lewis \& Sieck, 1992) and functional characteristics such as contractile and relaxation properties (Lewis et al. 1986; Nishio \& Jeejeebhoy, 1991), aerobic capacity (Layman et al. 1981) and resistance to fatigue (Barclay \& Loiselle, 1992). Restricted food intake of rats resulted in reduced muscle contents of total protein (Howarth \& Baldwin, 1971; Glore \& Layman, 1983; El Haj et al. 1986; Ocken \& Grunewald, 1988) and myofibrillar protein (Mosoni et al. 1996). Effects are generally more severe for fast-twitch than slow-twitch muscles and muscle fibres (Li \& Goldberg, 1976; Hansen-Smith et al. 1978; Goodman et al. 1981; Layman et al. 1981; Bedi et al. 1982).

Muscular growth can also be induced to varying degrees by the addition of load through exercise programmes or other experimental interventions. For example, plantaris or soleus muscles are forced to grow by functional overload after tenotomy or removal of synergist muscles (Noble et al. 1984; Tsika et al. 1987; Ianuzzo et al. 1991; Sugiura et al. 1993). This approach results in increased muscle mass, total protein and myofibrillar protein in the overloaded muscles (Noble et al. 1984; Tsika et al. 1987).

The overall objective of the present study was to investigate the effects of energy restriction on growth of

\footnotetext{
Abbreviations: CON100, CON81 and CON73, energy intake at 100, 81 and $73 \%$ of the ad libitum intake of the control diet respectively; MHC, myosin heavy chain.

$\leftarrow$ Presented in part at the 1997 17th International Congress of Biochemistry and Molecular Biology in San Francisco, CA, USA, and published in abstract form (Almurshed \& Grunewald, 1997).

$†$ Present address: Department of Community Health Sciences, King Saud University, Riyadh 11433, Saudi Arabia.

* Corresponding author: Dr Katharine Grunewald, fax +1 785532 3132, email grunew@humec.ksu.edu
} 
two muscles subjected to weight-bearing exercise through functional overload. Although endurance training has been shown to reduce the muscle-wasting effects of food restriction (Sakamoto \& Grunewald, 1987; Ballor et al. 1990), relatively few studies have employed weightbearing or resistance exercise designed to maximize muscular growth. Furthermore, most previous investigations employed chronic or acute feed restriction, i.e. the whole diet was reduced so that intake of all nutrients was reduced. Consequently, effects on muscular growth could not be attributed to energy restriction as a single effective factor. This information should strengthen and support our current understanding of muscular growth and how it is affected by the nutritional environment. In addition, it might benefit individuals who follow dietary practices designed to enhance muscular growth (Bazzarre et al. 1990; Kleiner et al. 1990; Grunewald \& Bailey, 1993).

In the present study we examined the effects of three levels of energy intake $(100,81$, and $73 \%$ of the ad libitum intake of the control diet) on growth of fast-twitch plantaris and slow-twitch soleus muscles subjected to functional overload. The energy-restricted diets were formulated to be nutritionally adequate except for energy. Growth indices studied were muscle mass, total and myofibrillar protein contents and myosin heavy-chain (MHC) isoform expression in male rats.

\section{Materials and methods \\ Experimental protocol}

The protocols for animal care and use were approved by the Institutional Animal Care and Use Committee of Kansas State University, Manhattan, KS, USA. The animals were cared for according to the guidelines of the National Institutes of Health on the experimental use of laboratory animals (National Research Council, 1985).

Male Sprague Dawley weanling rats (Harlan Sprague Dawley, Indianapolis, IN, USA) were housed in individual cages under a controlled temperature of $24^{\circ} \mathrm{C}$ and a $12 \mathrm{~h}$ light-dark cycle. At body weights of $200-220 \mathrm{~g}$, the rats were anaesthetized with halothane and the gastrocnemius muscle was removed from the left hindlimb to induce functional overload of the underlying plantaris and soleus muscles. The right hindlimb was sham-operated to serve as an intra-animal control.

Immediately following the surgical procedure, the rats were randomly allocated to one of the three experimental diets (Harlan Teklad, Madison, WI, USA; Table 1). Effects of three different levels of energy were tested. Control rats had free access to the AIN-76A diet (American Institute of Nutrition, 1977, 1980) and thus received a baseline $100 \%$ level of dietary energy (CON100). Rats in the two energyrestricted groups were fed either $75 \%$ or $90 \%$ of the daily amount of feed consumed by CON100 rats. The energyrestricted diets were formulated to be nutritionally similar to the control diet except for energy, when fed at the designated amounts. Animals in the three groups had free access to water.

After $30 \mathrm{~d}$ on their respective diets, the rats were fasted for $12-16 \mathrm{~h}$ and killed by exsanguination. Blood samples
Table 1. Composition of the experimental diets

\begin{tabular}{lccc}
\hline Diet $^{*} .$. & CON100 & CON81 & CON73 \\
\hline Ingredients (g/kg) & & & \\
Casein, high-protein & 200 & 222.23 & 266.67 \\
DL-Methionine & 3.00 & 3.34 & 4.00 \\
Sucrose & 499.99 & 473.4 & 420.1 \\
Maize starch & 150 & 142 & 126 \\
Maize oil & 50 & 55.56 & 66.67 \\
Fibre (cellulose) & 50 & 51.22 & 53.87 \\
Mineral mix, AIN-76† & 35.00 & 38.89 & 46.67 \\
Vitamin mix, AIN-76A $\ddagger$ & 10.00 & 11.12 & 13.34 \\
Choline bitartrate & 2.00 & 2.23 & 2.67 \\
Ethoxyquin (antioxidant) & 0.0100 & 0.0112 & 0.0134 \\
Energy: kJ/g & 15.7 & 15.7 & 15.7 \\
$\quad$ kJ/g protein & 90.0 & 81.3 & 67.8 \\
Composition by energy (\%)§ & & & \\
Protein & 18.54 & 20.57 & 24.68 \\
Fat & 12.50 & 13.86 & 16.62 \\
Carbohydrate & 68.95 & 65.57 & 58.70 \\
\hline
\end{tabular}

CON100, CON81, CON73, energy intake at 100,81 and $73 \%$ of the ad libitum intake of the control diet respectively.

* The CON100 diet is the AIN-76A diet (American Institute of Nutrition, 1977, 1980). The CON81 and CON73 diets were formulated to be nutritionally similar to the control diet except for energy. They were fed at 90 and $75 \%$ by weight of the CON100 diet respectively. All diets were purchased from Harlan Teklad, Madison, WI, USA.

† The AIN-76 mineral mix supplied the following (per kg mixture): calcium phosphate dibasic $500 \mathrm{~g}$, sodium chloride $74 \mathrm{~g}$, potassium citrate monohydrate $220 \mathrm{~g}$, potassium sulfate $52 \mathrm{~g}$, magnesium oxide $24 \mathrm{~g}$, manganous carbonate $3.5 \mathrm{~g}$, ferric citrate $6 \mathrm{~g}$, zinc carbonate $1.6 \mathrm{~g}$, cupric carbonate $300 \mathrm{mg}$, potassium iodate $10 \mathrm{mg}, \mathrm{Na}_{2} \mathrm{SeO}_{3 z \mathrm{rad} ;} 5 \mathrm{H}_{2} \mathrm{O} 10 \mathrm{mg}$, $\mathrm{KCr}\left(\mathrm{SO}_{4}\right)_{2 z \mathrm{rad}} ; 2 \mathrm{H}_{2} \mathrm{O} 550 \mathrm{mg}$, sucrose $118.03 \mathrm{~g}$.

‡ The AIN-76A vitamin mix supplied the following (per kg mixture): thiamin hydrochloride $600 \mathrm{mg}$, riboflavin $600 \mathrm{mg}$, pyridoxine hydrochloride $700 \mathrm{mg}$, niacin $3 \mathrm{~g}$, calcium pantothenate $1.6 \mathrm{~g}$, folic acid $200 \mathrm{mg}$, biotin $20 \mathrm{mg}$, vitamin $\mathrm{B}_{12}(0.1 \%$ trituration in mannitol) $1 \mathrm{~g}$, dry retinyl palmitate $800 \mathrm{mg}$, dry $\alpha$-tocopheryl acetate $10 \mathrm{~g}$, cholecalciferol trituration $250 \mathrm{mg}$, menadione-sodium bisulfite complex $150 \mathrm{mg}$, sucrose $981.08 \mathrm{~g}$.

$\S$ Estimations based on calculated energy values.

were collected into small vials and stored at $-70^{\circ} \mathrm{C}$. Plantaris and soleus muscles were removed from both hindlimbs, weighed, submerged in ice-cold glycerol and stored at $-70^{\circ} \mathrm{C}$ until required for analysis. Organ (liver, heart and kidneys) weights were recorded and the organs were wrapped in $\mathrm{Al}$ foil and stored at $-70^{\circ} \mathrm{C}$. Fat pad (epididymal, retroperitoneal and omental) weights were also recorded.

\section{Serum and tissue measurements}

Serum free fatty acids were assayed by the colorimetric method of Duncombe (1964) with modifications by Noma et al. (1973) and Laurell \& Tibbling (1966). Serum albumin was assayed using a colorimetric procedure (Sigma Kit no. 631; Sigma Chemical Co., St Louis, MO, USA). Serum glucose was determined by the glucose oxidase method (Sigma Kit no. 510). Blood urea-N was measured by a colorimetric procedure (Sigma Kit no. 535). Total protein contents of livers, kidneys, and hearts were determined using a Bio-Rad protein assay (Bio-Rad Laboratories, Hercules, CA, USA).

\section{Washed myofibrils preparation}

We used the method of Talmadge \& Roy (1993) to wash 
and prepare myofibrils. Frozen muscles were minced with scissors in $10 \mathrm{vol}$. (per unit muscle weight) ice-cold homogenization buffer (250 mM-sucrose, $100 \mathrm{mM}-\mathrm{KCl}$, 5 mM-EDTA $20 \mathrm{~mm}$-Tris (base), pH 6.8). The muscle minces were then homogenized using a high-speed Brinkmann Homogenizer (Sybron Corporation, Westbury, NY, USA). Total protein assays were performed on $0.1 \mathrm{ml}$ of the homogenate using the Bio-Rad protein assay employed for other tissues. The remainder of the homogenate was centrifuged in $4^{\circ} \mathrm{C}$ at $1000 \mathrm{~g}$ for $10 \mathrm{~min}$. The supernatant fraction was discarded and the myofibril pellet was resuspended in wash solution $(175 \mathrm{mM}-\mathrm{KCl}, 20 \mathrm{mM}-$ Tris (base), 2 mM-EDTA, $5 \mathrm{~g}$ Triton X-100/1, pH 6.8, at $6^{\circ} \mathrm{C}$ ) using the same volume as for the homogenization buffer. It was then centrifuged as described earlier and the supernatant fraction was discarded. The washing step was repeated and the resultant myofibril pellet was resuspended in $0.5 \mathrm{vol}$. (relative to the volume of the previous wash) resuspension buffer (150 $\mathrm{mM}-\mathrm{KCl}, 20 \mathrm{mM}$-Tris (base), $\mathrm{pH}$ $7 \cdot 0$, at $6^{\circ} \mathrm{C}$ ). This myofibril solution was used to determine myofibrillar protein content and $\mathrm{MHC}$ ratios in electrophoretic assays.

\section{Electrophoresis}

Electrophoresis was run in a Bio-Rad Mini-Protean II Dual Slab Cell electrophoretic system utilizing a Bio-Rad 1000/ 500 power supply (Bio-Rad Laboratories). Preparation of separating gels, stacking gels and running buffers was performed as described previously by Talmadge \& Roy (1993). Polymerization was initiated with $0.5 \mathrm{~g} \mathrm{~N}, \mathrm{~N}_{,} \mathrm{N}^{\prime}, \mathrm{N}^{\prime}$ tetramethylethylenediamine/l and $1 \mathrm{~g}$ ammonium persulfate/l. The washed myofibrils were boiled in sample buffer (10 ml mercaptoethanol/1, $138.7 \mathrm{mM}-\mathrm{SDS}, 160 \mathrm{mM}$-Tris (base), $250 \mathrm{ml}$ glycerol/1, $2 \mathrm{~g}$ bromophenol blue/l) for $1 \mathrm{~min}$ at a final concentration of $0.125 \mu \mathrm{g} / \mathrm{l}$ immediately before loading, cooled down to room temperature, and loaded at $5 \mu \mathrm{l}$ per well. The entire electrophoresis apparatus was placed in the refrigerator for the period of running $(24 \mathrm{~h})$ at $80 \mathrm{~V}$ (constant voltage). The gels were then Ag stained using the Bio-Rad silver stain plus kit (BioRad Laboratories). Bands were quantified using a Hewlett Packard 6100C ScanJet scanner (Hewlett Packard, Palo Alto, CA, USA) and Sigma Gel version 1.1 software (John Dell Scientific, Chicago, IL, USA).

\section{Statistical analysis}

We used a randomized complete block design, blocking for body weight and day of surgery. There were three diet groups, two legs (overloaded $v$. sham) and ten rats for each diet group. The response tested was the difference between the overloaded and sham-operated legs. ANOVA followed by the least squares means option in Statistical Analysis Systems statistical software package version 6.12 (SAS Institute, Cary, NC, USA) were used. Both linear and quadratic contrast were used to detect the main effect of the diet. Results were considered statistically significant at $P<$ 0.05 .
Table 2. Weight gain and feed intake of rats fed for $30 \mathrm{~d}$ of $100 \%$ (CON100), $81 \%$ (CON81) and $73 \%$ (CON73) of the ad libitum energy intake*

(Mean values with their pooled standard errors for ten rats)

\begin{tabular}{|c|c|c|c|c|}
\hline Diet group... & CON100 & CON81 & CON73 & $\begin{array}{c}\text { Pooled } \\
\text { SEM }\end{array}$ \\
\hline Initial body wt (g) & 215 & 213 & 214 & 2 \\
\hline Final body wt $(\mathrm{g}) \dagger$ & $346^{a}$ & $303^{b}$ & $289^{c}$ & 4 \\
\hline Body-wt gain $(\mathrm{g} / 30 \mathrm{~d}) \dagger$ & $132^{\mathrm{a}}$ & $91^{\mathrm{b}}$ & $75^{\mathrm{c}}$ & 4 \\
\hline Total feed intake $(\mathrm{g}) \dagger$ & $589^{a}$ & $481^{\mathrm{b}}$ & $427^{\mathrm{c}}$ & 8 \\
\hline Daily feed intake $(\mathrm{g} / \mathrm{d}) \dagger$ & $19 \cdot 6^{\mathrm{a}}$ & $16 \cdot 0^{b}$ & $14 \cdot 2^{c}$ & 0.3 \\
\hline Feed efficiency $(\mathrm{g} / \mathrm{g}) \dagger \ddagger$ & $0.22^{a}$ & $0.19^{b}$ & $0.18^{b}$ & 0.01 \\
\hline Energy intake $(\mathrm{kJ} / \mathrm{d}) \dagger$ & $310^{a}$ & $251^{\mathrm{b}}$ & $226^{c}$ & 4 \\
\hline \multicolumn{5}{|l|}{ Macronutrient intake $(\mathrm{g} / \mathrm{d})$} \\
\hline Proteint & $3 \cdot 42^{\mathrm{a}}$ & $3 \cdot 10^{\mathrm{b}}$ & $3 \cdot 31^{a}$ & 0.05 \\
\hline Fat† & $1.04^{\mathrm{a}}$ & $0.93^{\mathrm{b}}$ & $0.99^{\mathrm{c}}$ & 0.01 \\
\hline Carbohydrate $\dagger$ & $12 \cdot 7^{\mathrm{a}}$ & $9 \cdot 9^{b}$ & $7 \cdot 9^{c}$ & 0.2 \\
\hline
\end{tabular}

a,b,c Mean values within a row with unlike superscript letters were significantly different $(P<0.05)$

* For details of diets and procedures, see Table 1 and p. 698

$\uparrow$ Main treatment effect of diet was significant $(P<0.05)$.

$\ddagger$ Body weight gain/total feed intake.

\section{Results}

\section{Body-weight gain and feed intake}

Weight gain and feed intake of rats fed the three different energy levels are shown in Table 2. Over the $30 \mathrm{~d}$ period rats fed $75 \%$ and $90 \%$ the amount of feed consumed by CON100 rats consumed $73 \%$ and $81 \%$ of the energy respectively of CON100 rats $(P<0 \cdot 05)$. Thus, the energyrestricted groups are referred to as CON73 or CON81 to reflect the actual energy intake of the animals. Rats in the CON81 and CON73 groups respectively had lower feed efficiencies $(-14 \%$ and $-18 \%)$, weighed less $(-12 \%$ and $-16 \%$ and gained less weight $(-31 \%$ and $-43 \%)$ than CON100 rats $(P<0 \cdot 05)$.

\section{Tissue measurements}

Table 3 shows dietary energy effects on tissue and organ growth and serum measurements. Rats fed the energyrestricted CON81 and CON73 diets respectively had smaller livers $(-13 \%$ and $-19 \%)$, kidneys $(-14 \%$ and $-17 \%)$ and hearts $(-9 \%$ and $-14 \%)$, and lower epididymal $(-27 \%$ and $-27 \%)$, retroperitoneal $(-45 \%$ and $-35 \%)$ and omental $(-21 \%$ and $-23 \%)$ fat pad weights than CON100 rats $(P<0 \cdot 05)$. However, when normalized for body weight ( $\mathrm{g} / 100 \mathrm{~g}$ body weight), liver, kidney and heart weights were similar among the three dietary groups. Serum albumin, blood urea-N, free fatty acids, and glucose levels were also similar when comparing both groups of energy-restricted rats to CON100 rats.

\section{Plantaris measurements}

Plantaris muscle measurements are shown in Table 4. Data are presented separately for sham-operated (right hindlimb) and overloaded (left hindlimb) muscles, as well as the difference between those muscles (expressed as a percentage of the sham-operated value). In general, overloaded muscles weighed more (range 31-47 \%) and had more total 
Table 3. Organ, tissue and serum measurements for rats fed for $30 \mathrm{~d}$ at $100 \%$ (CON100), $81 \%$ (CON81) and $73 \%$ (CON73) of the ad libitum energy intake*

(Mean values with their pooled standard errors for ten rats)

\begin{tabular}{|c|c|c|c|c|}
\hline Diet group... & CON100 & CON81 & CON73 & $\begin{array}{l}\text { Pooled } \\
\text { SEM }\end{array}$ \\
\hline \multicolumn{5}{|l|}{ Liver } \\
\hline Wt: g† & $11 \cdot 3^{\mathrm{a}}$ & $9 \cdot 8^{b}$ & $9 \cdot 1^{b}$ & 0.3 \\
\hline $\mathrm{g} / 100 \mathrm{~g}$ body wt & 3.3 & 3.2 & 3.1 & 0.1 \\
\hline Total protein $(\mathrm{g}) \dagger$ & $1.98^{\mathrm{a}}$ & $1.95^{\mathrm{a}}$ & $1.58^{b}$ & 0.05 \\
\hline \multicolumn{5}{|l|}{ Kidneys } \\
\hline Wt: g† & $2 \cdot 58^{\mathrm{a}}$ & $2 \cdot 23^{b}$ & $2 \cdot 13^{b}$ & 0.05 \\
\hline $\mathrm{g} / 100 \mathrm{~g}$ body wt & 0.75 & 0.73 & 0.74 & 0.01 \\
\hline Total protein, (g) & 0.26 & 0.24 & 0.23 & 0.01 \\
\hline \multicolumn{5}{|l|}{ Heart } \\
\hline Wt: g† & $1.05^{\mathrm{a}}$ & $0.96^{b}$ & $0.90^{\mathrm{b}}$ & 0.02 \\
\hline $\mathrm{g} / 100 \mathrm{~g}$ body wt & 0.30 & 0.32 & 0.31 & 0.01 \\
\hline Total protein, $(\mathrm{g}) \dagger$ & $0.14^{a}$ & $0 \cdot 12^{b}$ & $0.12^{b}$ & 0.01 \\
\hline \multicolumn{5}{|l|}{ Fat pads $(\mathrm{g})$} \\
\hline Epididymal† & $4 \cdot 52^{\mathrm{a}}$ & $3 \cdot 29^{b}$ & $3.28^{b}$ & 0.14 \\
\hline Retroperitonealt & $2 \cdot 85^{a}$ & $1.56^{b}$ & $1.85^{\mathrm{b}}$ & 0.19 \\
\hline Omental† & $4 \cdot 13^{a}$ & $3.27^{b}$ & $3 \cdot 18^{b}$ & 0.12 \\
\hline \multicolumn{5}{|l|}{ Serum measurements } \\
\hline Albumin $(\mathrm{g} / \mathrm{l})$ & 35 & 35 & 35 & 1 \\
\hline Blood urea-N (mg/l) & 138 & 148 & 157 & 8 \\
\hline Free fatty acids $(\mathrm{mg} / \mathrm{l})$ & 86 & 83 & 93 & 11 \\
\hline Glucose $(\mathrm{mg} / \mathrm{l})$ & 990 & 880 & 890 & 40 \\
\hline
\end{tabular}

a,b,c Mean values within a row with unlike superscript letters were significantly different $(P<0.05)$

* For details of diets and procedures, see Table 1 and p. 698.

$\dagger$ Main treatment effect of diet was significant $(P<0.05)$

protein (range 31-52\%) and myofibrillar protein (range $27-51 \%$ ) than sham-operated muscles in all three treatment groups. Rats on the energy-restricted diets had smaller sham-operated plantaris muscles (CON73 -13\%, CON81-9\%) containing less total protein (CON73-14\%,

Table 4. Weights and protein contents of sham-operated (sham) and functionally-overloaded (overloaded) plantaris muscle from rats fed for $30 \mathrm{~d}$ at $100 \%$ (CON100), $81 \%$ (CON81) and $73 \%$ (CON73) of ad libitum energy intake*

(Mean values with their pooled standard errors for ten rats)

\begin{tabular}{|c|c|c|c|c|}
\hline Diet group... & CON100 & CON81 & CON73 & $\begin{array}{l}\text { Pooled } \\
\text { SEM }\end{array}$ \\
\hline \multicolumn{5}{|l|}{$\overline{\mathrm{Wt}}(\mathrm{mg})$} \\
\hline Sham† & $389^{a}$ & $354^{\mathrm{b}}$ & $339^{b}$ & 8 \\
\hline Overloaded & 510 & 498 & 497 & 16 \\
\hline Difference (\%)‡ & +31 & +42 & +47 & 4 \\
\hline \multicolumn{5}{|c|}{ Wt (mg/100 g body wt) } \\
\hline Sham & 112 & 116 & 117 & 2 \\
\hline Overloaded† & $147^{a}$ & $165^{\mathrm{b}}$ & $172^{\mathrm{b}}$ & 5 \\
\hline Difference (\%)‡ & +31 & +42 & +47 & 4 \\
\hline \multicolumn{5}{|l|}{ Total protein (mg) } \\
\hline Shamt & $70^{\mathrm{a}}$ & $63^{\mathrm{b}}$ & $60^{\mathrm{b}}$ & 2 \\
\hline Overloaded & 92 & 87 & 91 & 3 \\
\hline Difference (\%)‡ & +31 & +39 & +52 & 5 \\
\hline \multicolumn{5}{|c|}{ Myofibrillar protein (mg) } \\
\hline Sham† & $32 \cdot 4^{a}$ & $29 \cdot 2^{\mathrm{ab}}$ & $28 \cdot 5^{b}$ & $1 \cdot 2$ \\
\hline Overloaded & $40 \cdot 8$ & 41.4 & 43.1 & 2.0 \\
\hline Difference (\%)‡ & +27 & +43 & +51 & 8 \\
\hline
\end{tabular}

a,b,c Mean values within a row with unlike superscript letters were significantly different $(P<0.05)$

* For details of diets and procedures, see Table 1 and p. 698.

$\dagger$ Main treatment effect of diet significant $(P<0.05)$.

¥ Difference between overloaded value and sham value expressed as a percentage of the sham value.
Table 5. Weights and protein contents of sham-operated (sham) and functionally-overloaded (overloaded) soleus muscle from rats fed for $30 \mathrm{~d}$ at $100 \%$ (CON100), $81 \%$ (CON81) and $73 \%$ (CON73) of the ad libitum energy intake*

(Mean values with their pooled standard errors for ten rats)

\begin{tabular}{|c|c|c|c|c|}
\hline Diet group... & CON100 & CON81 & CON73 & $\begin{array}{c}\text { Pooled } \\
\text { SEM }\end{array}$ \\
\hline \multicolumn{5}{|l|}{ Wt (mg) } \\
\hline Sham & 112 & 114 & 105 & 3 \\
\hline Overloaded & 133 & 145 & 130 & 6 \\
\hline Difference $(\%) \dagger$ & +19 & +26 & +25 & 5 \\
\hline \multicolumn{5}{|c|}{ Wt (mg/100 g body wt) } \\
\hline Sham $\ddagger$ & $32^{\mathrm{a}}$ & $38^{\mathrm{b}}$ & $36^{\mathrm{b}}$ & 1 \\
\hline Overloaded $\ddagger$ & $38^{\mathrm{a}}$ & $48^{\mathrm{b}}$ & $45^{\mathrm{b}}$ & 2 \\
\hline Difference, $(\%) \dagger$ & +19 & +26 & +25 & 5 \\
\hline \multicolumn{5}{|l|}{ Total protein (mg) } \\
\hline Sham & 19 & 20 & 19 & 1 \\
\hline Overloaded & 24 & 26 & 23 & 1 \\
\hline Difference (\%)† & +22 & +29 & +26 & 4 \\
\hline \multicolumn{5}{|c|}{ Myofibrillar protein (mg) } \\
\hline Sham & $9 \cdot 1^{\mathrm{ab}}$ & $9 \cdot 6^{a}$ & $8 \cdot 4^{\mathrm{b}}$ & 0.3 \\
\hline Overloaded & $10 \cdot 7$ & 11.9 & $10 \cdot 8$ & 0.4 \\
\hline Difference $(\%) \dagger$ & +18 & +23 & +29 & 5 \\
\hline
\end{tabular}

${ }^{\mathrm{a}, \mathrm{b}, \mathrm{c}}$ Mean values within a row not sharing a common superscript letter were significantly different $(P<0.05)$

* For details of diets and procedures, see Table 1 and p. 698.

$\dagger$ Difference between overloaded value and sham value expressed as a percentage of the sham value.

‡ Main treatment effect of diet was significant $(P<0.05)$.

CON81 $-10 \%)$ and myofibrillar protein (CON73 - $12 \%)$ than CON100 rats $(P<0 \cdot 05)$. In contrast, energy restriction did not affect growth of the plantaris muscles subjected to functional overload because muscle mass $(\mathrm{mg})$, total protein, and myofibrillar protein measurements were similar among the three dietary groups. Furthermore, normalized weights (mg/100 g body weight) of the overloaded plantaris muscles were greater for CON73 and CON81 rats than for CON100 rats $(P<0 \cdot 05)$.

\section{Soleus measurements}

Measurements for soleus muscles are shown in Table 5. Overloaded soleus muscles weighed more than shamoperated muscles (range 19-25\%), and contained more total protein (range 22-29\%) and myofibrillar protein (range 18-29\%) in all three treatment groups. However energy-restricted diets had little effect on soleus muscle growth. Soleus weights $(\mathrm{mg})$ and total protein contents were similar among CON100, CON81 and CON73 groups for both sham-operated and overloaded muscles. Shamoperated soleus of CON73 rats had less myofibrillar protein $(-8 \%)$ than those in CON100 rats $(P<0 \cdot 05)$. Normalized soleus weights $(\mathrm{mg} / 100 \mathrm{~g}$ body weight) were greater for rats in the CON73 and CON81 groups than for those in the CON100 group for both sham-operated and overloaded muscles $(P<0.05)$.

\section{Myosin heavy chain isoforms}

Fig. 1 shows sample MHC isoform separations of plantaris and soleus muscles using the minigel system and $\mathrm{Ag}$ staining. We obtained good resolution of the four MHC bands of the plantaris (types I, IIa, IIx, IIb) and the two 


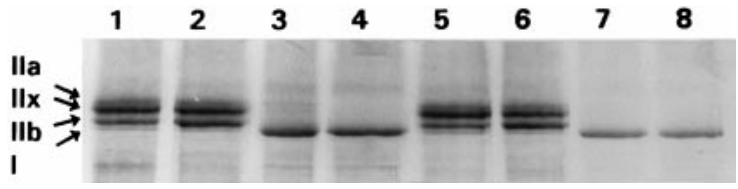

Fig. 1. SDS-PAGE of myosin heavy-chain (MHC) isoforms (types I, $\mathrm{Ila}, \mathrm{Ilx}, \mathrm{Ilb}$ ) in functionally-overloaded and sham-operated plantaris and soleus muscles of rats fed for $30 \mathrm{~d}$ at $100 \%$ (CON100), $81 \%$ (CON81) and $73 \%$ (CON73) of the ad libitum energy intake. Lane 1 , CON100 overloaded plantaris; lane 2, CON100 sham plantaris; lane 3 , CON100 overloaded soleus; lane 4, CON100 sham soleus; lane 5 , CON81 overloaded plantaris; lane 6 , CON81 sham plantaris; lane 7, CON81 overloaded soleus; lane 8, CON81 sham soleus. Good resolution was obtained for all four $\mathrm{MHC}$ bands in the plantaris and for two MHC bonds (types I, Ila) in the soleus. For details of diets and procedures, see Table 1 and p. 698.

MHC bands of the soleus (types I, IIa). Fig. 2 shows the distribution of $\mathrm{MHC}$ isoforms in plantaris and soleus muscles. Rats fed the CON100, CON81, and CON73 diets for $30 \mathrm{~d}$ had similar MHC distribution in plantaris muscles (types I, IIa, IIx, IIb) and in soleus muscles (types I, IIa). The MHC distribution of those muscles was also similar in sham-operated and overloaded muscles.

(a)

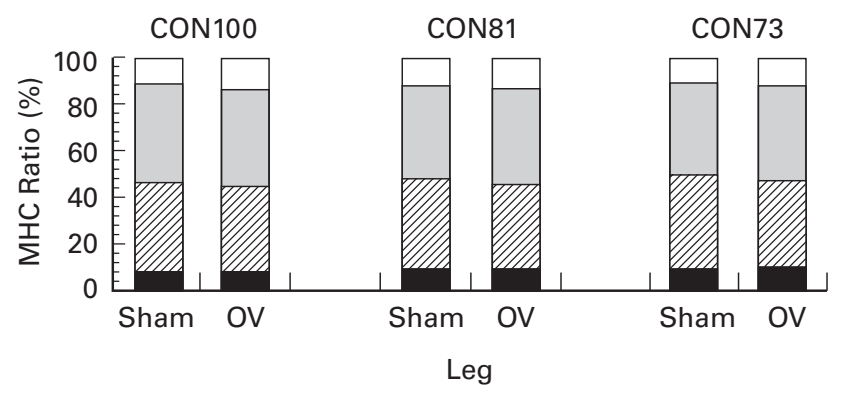

(b)

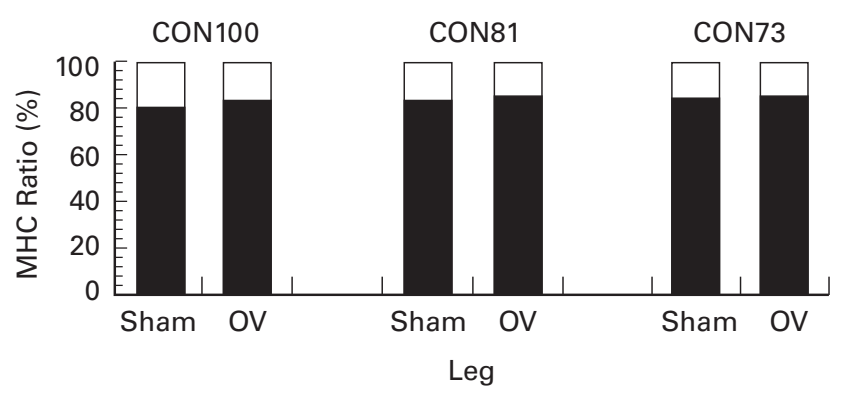

Fig. 2. Myosin heavy-chain (MHC) isoform ratios in sham-operated (sham) and functionally-overloaded (OV) (a) plantaris and (b) soleus leg muscles of rats fed for $30 \mathrm{~d}$ at $100 \%$ (CON100), $81 \%$ (CON81) and $73 \%$ (CON73) of the ab libitum energy intake. MHC isoforms are $\square$ Type Ila, 䛜 Type IIx, Type Ilb and Type I. Values are means for ten rats. No significant differences were observed between dietary treatment groups. For details of diets and procedures, see Table 1 and p. 698.

\section{Discussion}

Our study showed that two levels of energy restriction, moderate and severe, did not compromise or affect growth of plantaris or soleus muscles subjected to functional overload in rats; as values for muscle mass, total protein and myofibrillar protein were similar in overloaded muscles among rats fed the different energy levels for a $30 \mathrm{~d}$ period. These effects were noted in both plantaris and soleus muscles. In contrast, sham-operated muscles were more sensitive to the growth-limiting effects of energy deprivation. Sham-operated plantaris muscles of rats fed the energy-restricted diets weighed less and contained less protein than those of control rats. The differences were not observed in soleus muscles. Other indices of reduced growth exhibited by the energy-restricted animals included lower body weight, smaller visceral organs and smaller fat depots. These effects have been shown in previous studies (Hill et al. 1970; Hegarty \& Kim, 1980, 1981; Ocken \& Grunewald, 1988).

The growth maintenance by overloaded, but not shamoperated, muscles in our study suggests that the additional muscular activity made them more resistant to the effects of energy deprivation. This finding is supported by data from other studies. For example, enforced stretch made extensor digitorum longus muscles more resistant to the wasting effects of starvation (Goldspink, 1978), feed-restricted mice trained to pull a cord had larger biceps brachii muscles than untrained feed-restricted mice (Goldspink, 1964), and treadmill exercise helped to conserve lean body mass in rats fed restricted diets (Sakamoto \& Grunewald, 1987; Ballor et al. 1990). Human studies have also shown that resistance training during energy restriction enhances the maintenance of lean body weight (Ballor et al. 1988; Bryner et al. 1999).

In the absence of loading or weight-bearing activity, effects of feed deprivation appear to be more severe on fast-twitch plantaris muscles than slow-twitch soleus muscles. In the present study, the sham-operated plantaris muscles were smaller in energy-restricted rats than in control rats; but these differences were not observed in soleus muscles. Thus, soleus muscles were relatively resistant to the effects of energy deprivation. There are several explanations for this finding. First, the soleus is primarily an anti-gravitational muscle, and the constant loading probably attenuated the growth-reducing effects of energy restriction. In contrast, the plantaris is primarily a locomotion muscle that is used less frequently. Second, there is an abundance of information which shows that nutritional deprivation effects are generally more severe for fast-twitch than slow-twitch muscles or muscle fibres (Goodman et al. 1981; Layman et al. 1981; Bedi et al. 1982). The reduction of protein synthesis was more severe in pale extensor digitorum longus muscles than in dark soleus muscles ( $\mathrm{Li} \&$ Goldberg, 1976). It has been suggested that the preservation of slow-twitch muscle over fast-twitch muscle is more economical from an energy standpoint, because slow-twitch fibres have a lower energy cost for contraction or isometric tension (Crow \& Kushmerick, 1982; Henriksson, 1990).

Muscle fibre type has been correlated with the content of 
specific MHC isoforms (Staron, 1991; Oishi, 1993) and so MHC isoform measurements were performed in our study. Myosins comprise a major portion of skeletal muscle proteins; and four MHC isoforms are expressed in rodent muscle (Pette \& Staron, 1990). Fast-twitch muscle such as the plantaris expresses types IIa, IIb and IIx MHC, whereas slow-twitch muscle such as the soleus expresses primarily type I and smaller amounts of type IIa MHC (Talmadge \& Roy, 1993; Sullivan et al. 1995; Demirel et al. 1999). These observations were shown and supported by our data. We also demonstrated that the MHC ratios expressed in soleus and plantaris muscles were not altered by energy deprivation over a $30 \mathrm{~d}$ period. Thus, this component of skeletal muscle appears to be resistant to the levels of energy deprivation used in our study.

The energy-restricted diets in our study were formulated to be nutritionally adequate except for energy. Thus, the two energy-restricted diets contained higher concentrations of protein, vitamins and minerals so that they could be fed in smaller amounts (90\% and $75 \%$ by weight of that fed to the control animals). We could therefore test the effects of energy deprivation as a single factor without inducing other nutritional deficiencies. This approach was taken because most previous studies had employed chronic or acute feed restriction where all nutrients were reduced in the diet, and so energy could not be tested as a single factor. However, the animals fed the energy-restricted diets ate less feed than that offered; the CON90 rats ate $81 \%$, and the CON75 rats ate $73 \%$ of that consumed by control rats. This lower intake can be attributed mostly to feed spillage of the CON81 and CON73 rats since all animals in the restricted groups were fed controlled amounts of feed each day. Protein intake of the CON81 rats was slightly less than that of the CON100 rats, but still nutritionally adequate. Nonetheless, we were able to test the effects of two different energy-restricted diets that were nutritionally adequate in other respects. The growth-reduction effects observed in the present study are similar to those published for acute or chronic feed restriction (Hill et al. 1970; Hegarty \& Kim, 1980, 1981; Ocken \& Grunewald, 1988).

Several methods have been used to experimentally induce skeletal muscle growth with varying degrees of success. Animals have been trained to work using food as a reward (Goldspink, 1964; Watt et al. 1982; Yarasheski et al. 1990). Other models include electrical stimulation (Garner et al. 1991; Caiozzo et al. 1992; Tamaki et al. 1992) and weighted stretch (Gollnick et al. 1983; Antonio \& Gonyea, 1993). The approach used in our investigation, functional overload by removal of synergist muscles, has well-documented effects on muscle growth and composition (Noble et al. 1984; Tsika et al. 1987; Ianuzzo et al. 1991; Sugiura et al. 1993). This method was particularly appropriate for our study because it produced rapid growth in a short period of time, an important feature for nutritional deprivation studies. Furthermore, food was not given as a reward for work, as this approach may be problematic if rats become physically compromised by the diet and are therefore less able to work (e.g. pull a lever, jump for food).

Another strength of our experimental approach was the two-leg (sham, overloaded) intra-animal design. This approach allowed us to observe the effects of energy restriction on two types of skeletal muscle growth: (1) normal growth occurring in sham-operated muscles, and (2) experimentally-induced rapid growth induced in overloaded muscles. Studying muscles from both hindlimbs in the same animal also allowed for comparison of genetically-identical muscles exposed to the same nutritional environment.

In conclusion, the present study shows the effects of two levels of energy restriction on several indices of growth of slow-twitch soleus and fast-twitch plantaris skeletal muscles in rats. We examined effects on normal growth of sham-operated muscles and on experimentally-induced growth of overloaded muscles. In the absence of loading, growth of fast-twitch plantaris muscle was reduced by energy restriction. Plantaris muscles subjected to functional overload, however, were not affected by energy restriction. Soleus muscles were more resistant to the effects of energy deprivation.

\section{Acknowledgements}

This study was supported by the Kansas Agricultural Experiment Station, contribution no. 99-455-J. We thank Dr James Higgins, Department of Statistics, Kansas State University, for his assistance in performing the statistical analyses.

\section{References}

Almurshed K \& Grunewald K (1997) Energy restriction effects on surgically-induced muscular hypertrophy in rats. The FASEB Journal 11, A954 Abstr.

American Institute of Nutrition (1977) Report of the American Institute of Nutrition ad hoc committee on standards for nutritional studies. Journal of Nutrition 107, 1340-1348.

American Institute of Nutrition (1980) Second report of the ad hoc committee on standards for nutritional studies. Journal of Nutrition 110, 1726.

Antonio J \& Gonyea WJ (1993) Progressive stretch overload of skeletal muscle results in hypertrophy before hyperplasia. Journal of Applied Physiology 75, 1263-1271.

Ballor DL, Katch VL, Becque MD \& Marks CR (1988) Resistance weight training during caloric restriction enhances lean body weight maintenance. American Journal of Clinical Nutrition 47, $19-25$.

Ballor DL, Tommerup LJ, Smith DB \& Thomas DP (1990) Body composition, muscle and fat pad changes following two levels of dietary restriction and/or exercise training in male rats. International Journal of Obesity 14, 711-722.

Barclay CJ \& Loiselle DS (1992) Dependence of muscle fatigue on stimulation protocol: effect of hypocaloric diet. Journal of Applied Physiology 72, 2278-2284.

Bazzarre TL, Kleiner SM \& Litchford MD (1990) Nutrient intake, body fat, and lipid profiles of competitive male and female bodybuilders. Journal of the American College of Nutrition $\mathbf{9}$, 136-142.

Bedi KS, Birzgalis AR, Mahon M, Smart JL \& Wareham AC (1982) Early life undernutrition in rats. British Journal of Nutrition 47, 417-430.

Bryner RW, Ullrich IH, Sauers J, Donley D, Hornsby G, Kolar M \& Yeater R (1999) Effects of resistance vs. aerobic training combined with an 800 calorie liquid diet on lean body mass and 
resting metabolic rate. Journal of the American College of Nutrition 18, 115-121.

Caiozzo VJ, Ma E, McCue SA, Smith E, Herrick RE \& Baldwin KM (1992) A new animal model for modulating myosin isoform expression by altered mechanical activity. Journal of Applied Physiology 73, 1432-1440.

Crow MT \& Kushmerick MJ (1982) Chemical energetics of slowand fast-twitch muscles of the mouse. Journal of General Physiology 79, 147-166.

Demirel HA, Powers SK, Naito H, Hughes M \& Coombes JS (1999) Exercise-induced alterations in skeletal muscle myosin heavy chain phenotype: dose-response relationship. Journal of Applied Physiology 86, 1002-1008.

Duncombe WG (1964) The colorimetric micro-determination of non-esterified fatty acids. Clinica Chimica Acta 9, 122-125.

El Haj AJ, Lewis SEM, Goldspink DF, Merry BJ \& Holeham AM (1986) The effect of chronic and acute dietary restriction on the growth and protein turnover of fast and slow types of rat skeletal muscle. Comparative Biochemistry and Physiology 85A, 281-287.

Garner RP, Terracio L, Borg TK \& Buggy J (1991) Intracranial self-stimulation motivates weight-lifting exercise in rats. Journal of Applied Physiology 71, 1627-1631.

Glore SR \& Layman DK (1983) Cellular growth of skeletal muscle in weanling rats during dietary restrictions. Growth $\mathbf{4 7}$, 403-410.

Goldspink DF (1978) The effects of food deprivation on protein turnover and nucleic acid concentrations of active and immobilized extensor digitorum longus muscles of the rat. Biochemistry Journal 176, 603-606.

Goldspink G (1964) The combined effects of exercise and reduced food intake on skeletal muscle fibers. Journal of Cellular and Comparative Physiology 63, 209-216.

Goldspink G (1980) Growth of muscle. In Development and Specialization of Skeletal Muscle, pp. 19-35 [DF Goldspink, editors]. New York: Cambridge University Press.

Gollnick PD, Parsons D, Riedy M \& Moore RL (1983) Fiber number and size in overloaded chicken anterior latissimus dorsi muscle. Journal of Applied Physiology 54, 1292-1297.

Goodman MN, McElaney MA \& Ruderman NB (1981) Adaptation to prolonged starvation in the rat: curtailment of skeletal muscle proteolysis. American Journal of Physiology 241, E321-E327.

Grunewald KK \& Bailey RS (1993) Commercially marketed supplements for bodybuilding athletes. Sports Medicine 15, 90 103.

Hansen-Smith FM, Van Horn DL \& Maksud MG (1978) Cellular response of rat quadriceps muscle to chronic dietary restrictions. Journal of Nutrition 108, 248-255.

Hegarty PVJ \& Kim KO (1980) Changes in skeletal muscle cellularity in starved and refed young rats. British Journal of Nutrition 44, 123-127.

Hegarty PVJ \& Kim KO (1981) Effect of starvation on tissues from the young of four species, with emphasis on the number and diameter of skeletal muscle fibers. Pediatric Research 15, $128-132$.

Henriksson J (1990) The possible role of skeletal muscle in the adaptation to periods of energy deficiency. European Journal of Clinical Nutrition 44, 55-64.

Hill DE, Holt AB, Parra A \& Cheek DB (1970) The influence of protein-calorie versus calorie restriction on the body composition and cellular growth of muscle and liver in weanling rats. John Hopkins Medical Journal 127, 146-163.

Howarth RE \& Baldwin RL (1971) Synthesis and accumulation of protein and nucleic acid in rat gastrocnemius muscle during normal growth, restricted growth, and recovery from restricted growth. Journal of Nutrition 101, 477-484.
Ianuzzo CD, Hamilton N \& Li B (1991) Competitive control of myosin expression: hypertrophy vs. hyperthyroidism. Journal of Applied Physiology 70, 2328-2330.

Kleiner SM, Bazzarre TL \& Litchford MD (1990) Metabolic profiles, diet and health practices of championship male and female body-builders. Journal of the American Dietetic Association 90, 962-967.

Lanz JK Jr, Donahoe M, Rogers RM \& Ontell M (1992) Effects of growth hormone on diaphragmatic recovery from malnutrition. Journal of Applied Physiology 73, 801-805.

Laurell S \& Tibbling G (1966) An enzymatic fluorometric micromethod for the determination of glycerol. Clinica Chimica Acta 13, 317-322.

Layman DK, Hegarty PVJ \& Swan PB (1980) Comparison of morphological and biochemical parameters of growth in rat skeletal muscles. Journal of Anatomy 130, 159-171.

Layman DK, Merdian-Bender M, Hegarty PVJ \& Swan PB (1981) Changes in aerobic and anaerobic metabolism in rat cardiac and skeletal muscles after total or partial dietary restrictions. Journal of Nutrition 111, 994-1000.

Lewis MI \& Sieck GC (1992) Effect of acute nutritional deprivation on diaphragm structure and function in adolescent rats. Journal of Applied Physiology 73, 974-978.

Lewis MI, Sieck GC \& Fournier M (1986) Effect of nutritional deprivation on diaphragm contractility and muscle fiber size. Journal of Applied Physiology 60, 596-603.

Li JB \& Goldberg AL (1976) Effects of food deprivation on protein synthesis and degradation in rat skeletal muscles. American Journal of Physiology 231, 441-448.

Mosoni L, Malmezat T, Valluy M-C, Houlier M-L \& Mirand PP (1996) Muscle and liver protein synthesis adapt efficiently to food deprivation and refeeding in 12-month-old rats. Journal of Nutrition 126, 516-522.

National Research Council (1985) In Guide for the Care and Use of Laboratory Animals. Publication no. 85-23. Bethesda, MD: National Institutes of Health.

Nishio ML \& Jeejeebhoy KN (1991) Skeletal muscle relaxation rate after fasting or hypocaloric feeding. Journal of Applied Physiology 71, 204-209.

Noble EG, Tang Q \& Taylor PB (1984) Protein synthesis in compensatory hypertrophy of rat plantaris. Canadian Journal of Physiology and Pharmacology 62, 1178-1182.

Noma A, Okabe H \& Kita M (1973) A new colorimetric microdetermination of free fatty acids in serum. Clinica Chimica Acta 43, 317-320.

Ocken DA \& Grunewald KK (1988) The effects of exercise on catch-up growth of rats recovering from early undernutrition. Journal of Nutrition 118, 1410-1416.

Oishi Y (1993) Relationship between myosin heavy chain IId isoform and fiber types in soleus muscle of the rat after hindlimb suspension. European Journal of Applied Physiology 66, 451-454.

Pette D \& Staron RS (1990) Cellular and molecular diversities of mammalian skeletal muscle fibers. Reviews of Physiology, Biochemistry, and Pharmacology 116, 1-76.

Sakamoto K \& Grunewald KK (1987) Beneficial effects of exercise on growth of rats during intermittent fasting. Journal of Nutrition 117, 390-395.

Staron RS (1991) Correlation between myofibrillar ATPase activity and myosin heavy chain composition in single human muscle fibers. Histochemistry 96, 21-24.

Sugiura T, Miyata H, Kawai Y, Matoba H \& Murakami N (1993) Changes in myosin heavy chain isoform expression of overloaded rat skeletal muscles. International Journal of Biochemistry 25, 1609-1613.

Sullivan VK, Powers SK, Criswell DS, Tumer N, Larochelle JS \& Lowenthal D (1995) Myosin heavy chain composition in young 
and old rat skeletal muscle: effects of endurance exercise. Journal of Applied Physiology 78, 2115-2120.

Talmadge RJ \& Roy RR (1993) Electrophoretic separation of rat skeletal muscle myosin heavy-chain isoforms. Journal of Applied Physiology 73, 2337-2340.

Tamaki T, Uchiyama S \& Nakano S (1992) A weight-lifting exercise model for inducing hypertrophy in the hindlimb muscles of rats. Medicine and Science in Sports and Exercise 24, 881-886.

Tsika RW, Herrick RE \& Baldwin KM (1987) Interaction of compensatory overload and hindlimb suspension on myosin isoform expression. Journal of Applied Physiology 62, 21802186.
Watt PW, Kelly FJ, Goldspink DF \& Goldspink G (1982) Exercise-induced morphological and biochemical changes in skeletal muscles of the rat. Journal of Applied Physiology 53, $1144-1151$.

Yarasheski KE, Lemon PWR \& Gilloteaux J (1990) Effect of heavy-resistance exercise training on muscle fiber composition in young rats. Journal of Applied Physiology 69, 434-437.

Young VR (1970) The role of skeletal and cardiac muscle in the regulation of protein metabolism. In Mammalian Protein Metabolism, vol. 4, pp. 585-728 [HN Munro, editor]. New York and London: Academic Press. 